THE EROTIC BIRD 



\section{THE EROTIC BIRD}

PHENOMENOLOGY IN LITERATURE

\section{Maurice Natanson}

With a foreword by Judith Butler 


\section{Copyright $(c) 1998$ by Princeton University Press}

Published by Princeton University Press, 41 William Street, Princeton, New Jersey 08540

In the United Kingdom: Princeton University Press, Chichester, West Sussex All Rights Reserved

\section{Library of Congress Cataloging-in-Publication Data}

Natanson, Maurice Alexander, 1924-

The erotic bird : phenomenology in literature / Maurice Natanson ; with a foreword by Judith Butler.

p. $\mathrm{cm}$.

Includes bibliographical references and index.

ISBN 0-691-01219-9 (cl : alk. paper)

1. Philosophy and literature. 2. Phenomenology in literature.

3. Phenomenology and literature. 4. Literature, Modern-History and criticism. I. Title.

PN49.N35 1997

$809^{\prime} .93384-\mathrm{dc} 21$

This book has been composed in Galliard

Princeton University Press books are printed on acid-free paper and meet the guidelines for permanence and durability of the Committee on Production Guidelines for Book Longevity of the Council on Library Resources

http://pup.princeton.edu

Printed in the United States of America

$\begin{array}{llllllllll}10 & 9 & 8 & 7 & 6 & 5 & 4 & 3 & 2 & 1\end{array}$ 


\section{Kathy Victoria Natanson}

Her miniature railroad

Standing in front of her;

Wearing an engineer's cap,

She holds up one hand-

The palm showing-

An adult woman,

Looking at you directly,

A greeting of acknowledgment

From a being unto death,

Calling for nothing,

But giving everything left

A smile can provide:

The right to farewell,

The right to recognition,

The right to wave back,

As trainmen always do.

In that moment of forgiveness,

The world shatters us

In the acceptance

Of what is transient:

The present as a hurtling

And an irremediable hurt. 
